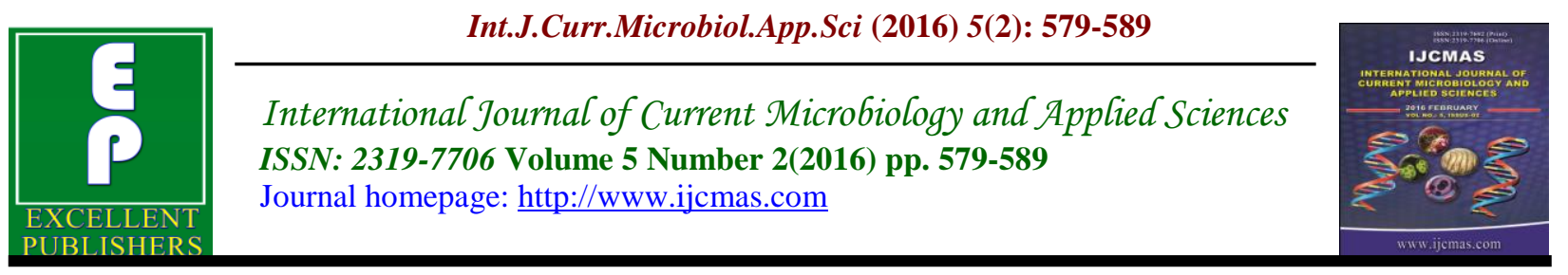

Original Research Article

doi: http://dx.doi.org/10.20546/ijcmas.2016.502.065

\title{
Activity of Glucose Isomerase from Bacillus thuringiensis under Different Treatments
}

\author{
Hamed M. El-Shora*, Ahmed M El-Shobaky and Jehan E Ghoneim \\ Botany Department, Faculty of Science, Mansoura University, Egypt \\ *Corresponding author
}

\begin{abstract}
A B S T R A C T
Keywords

Glucose isomerase, Purification, Bacillus thuringiensis, characteristics.

Article Info

Accepted:

26 January 2016

Available Online:

10, February 2016

Bacillus thuringiensis is a Gram-positive bacterium naturally found in soil, water and grain dust, and can be cultivated in liquid, solid and semi-solid media. Glucose isomerase (EC. 5.3.1.5) catalyzes the reversible isomerization of glucose to fructose and that of xylose to xylulose. It is an important enzyme used in the industrial production of high-fructose corn syrup (HFCS). Glucose isomerase was purified from Bacillus thuringiensis. The final purification resulted in a considerably high yield $(64.6 \%)$ with about 15.8 -fold. The optimum temperature and $\mathrm{pH}$ were $50{ }^{\circ} \mathrm{C}$ and 7.0 . The optimum glucose concentration was $8 \mathrm{mM}$. Glucose isomerase required $\mathrm{Mn}^{2+}$ or $\mathrm{Ca}^{2+}$ as cofactor. The enzyme was activated by cysteine, ascorbic acid, folic acid and sodium sulfate. The enzyme was inhibited by sodium bromide, sodium azide, sodium fluoride, sodium arsenate, glycine, tyrosine, phenylalanine, arginine, asparagine, and guanidine hydrochloride. Pyruvate, glyoxylate and 2-oxoglutarate inhibited the enzyme activity at the higher concentrations.
\end{abstract}

\section{Introduction}

Glucose isomerase enzyme was found in several bacteria which can utilize xylose as a carbon substrate for growth (Chen, 1980). The physiological function of the enzyme in vivo is to convert D-glucose into D-fructose (Takasaki et al., 1969).

Glucose isomerase has gained more interest due to its potential applications in the biofuel industry in addition to food industry. Ethanol is the major form of biofuel, and numerous technologies have been used to improve its production (Bangrak et al.,
2011; Mohammadi et al., 2011; Tao et al., 2011).

Various microorganisms have been found to produce glucose isomerase (Deshmukh et al., 1994; Belfaquih and Penninckx., 2000; Givry and Duchiron, 2007). The conversion of glucose to fructose chemically has been known to demand high $\mathrm{pH}$ and temperature. The possibility of producing fructose chemically from glucose has been studied by Barker et al. (1973). 
Chemically produced fructose has off flavors and reduced sweetness, which cannot be easily remedied. Thus, it cannot be used commercially. In addition, enzymatic conversion of glucose to fructose has several advantages such as (i) the reaction requirement of ambient conditions of $\mathrm{pH}$ and temperature, (ii) specificity of the reaction and (iii) the reaction proceeds without side products. Thus, the enzymatic conversion of glucose to fructose is better than the chemical isomerization (Anbu et al., 2013).

The cost of enzyme production is an important factor in evaluation of its suitability for industrial application. One way to reduce the cost of glucose isomerase production is to reuse it several times and to recover it efficiently. Immobilization of glucose isomerase offers an excellent opportunity for its effective reuse. The largest market for glucose isomerase in the immobilized form has become of great interest (Verhoff et al., 1985; Pedersen, 1993).

Several methods for immobilizing of glucose isomerase have been described. However, a few methods are economical and yield enzyme preparations with properties that are acceptable for commercial high-fructose corn syrup (HFCS) (Antrim et al., 1979).

The ability of glucose isomerase to isomerize a variety of substrates including pentoses, hexoses, sugar alcohols and sugar phosphates was investigated. The enzyme was able to utilize D-ribose, L-rhamnose, Larabinose and 2-deoxyglucose beside Dglucose and D-xylose (Chen, 1980).

The aim of the present work was to determine the activity of glucose isomerase purified from Bacillus thuringiensis under different treatment.

\section{Material and Methods}

\section{Source of the Enzyme}

Bacillus thuringiensis was the organism used in the isolation, purification of glucose isomerase and studying the response of the enzyme to various effectors.

\section{Growth of Bacillus thuringiensis}

The pure culture was inoculated into a 250 $\mathrm{ml}$ conical flask containing $250 \mathrm{ml}$ of culture medium (peptone $1 \mathrm{~g}$, yeast extract $0.5 \mathrm{~g}, \quad \mathrm{~K}_{2} \mathrm{HPO}_{4} \quad 0.3 \mathrm{~g}, \quad \mathrm{MgSO}_{4} .7 \mathrm{H}_{2} \mathrm{O} \quad 1 \mathrm{~g}$, xylose $1 \mathrm{~g}$, distilled water $250 \mathrm{ml}, \mathrm{pH} 7.0$ followed by incubating at $37{ }^{\circ} \mathrm{C}$ on shaker for $24 \mathrm{~h}$.

\section{Enzyme Production and Extraction}

Bacterial cells grown in $250 \mathrm{ml}$ of medium described above were harvested by centrifugation at $3000 \mathrm{~g}$ for $15 \mathrm{~min}$ and then washed twice with $0.2 \mathrm{M}$ phosphate buffer $(\mathrm{pH}$ 7.0). After washing the cell suspension was treated with 5\% Triton X-100 for 10 min to disrupt the cell membrane. Following disruption, the mixture was centrifuged at $3000 \mathrm{~g}$ for $15 \mathrm{~min}$. The resulting supernatant was used to measure the enzyme activity.

\section{Enzyme Production and Extraction}

Bacterial cells grown in $250 \mathrm{ml}$ of medium described above were harvested by centrifugation at $3000 \mathrm{~g}$ for $15 \mathrm{~min}$ and then washed twice with $0.2 \mathrm{M}$ phosphate buffer (pH 7.0).

After washing the cell suspension was treated with $5 \%$ Triton $\mathrm{X}-100$ for $10 \mathrm{~min}$ to disrupt the cell membrane. Following disruption, the mixture was centrifuged at $3000 \mathrm{~g}$ for $15 \mathrm{~min}$. The resulting supernatant was used to measure the enzyme activity. 


\section{Enzyme Assay}

One $\mathrm{ml}$ of the prepared enzyme solution was added to a test tube and incubated with $2 \mathrm{ml}$ of $100 \mathrm{mM}$ phosphate buffer ( $\mathrm{pH} 7.0$ ) containing $1 \%$ glucose for $25 \mathrm{~min}$ followed. The tubes were then kept in iced bath for 30 min. The formed fructose was determined by the method of Kulka (1956). Aliquot (0.5 $\mathrm{ml})$ of the reaction mixture was mixed with $1.5 \mathrm{ml}$ distilled water. Then $6 \mathrm{ml}$ of ketose reagent [1:1 ratio of $\mathrm{A}(0.05 \mathrm{~g}$ resorcinol in $100 \mathrm{ml}$ ethanol] and $\mathrm{B}\left[0.216 \mathrm{~g} \mathrm{FeNH}_{4}\right.$ $\left(\mathrm{SO}_{4}\right)_{2} .12 \mathrm{H}_{2} \mathrm{O}$ in $1000 \mathrm{ml} \mathrm{HCl}$ solution] was added. The tube containing the mixture was placed in a water bath at $80^{\circ} \mathrm{C}$ for $30 \mathrm{~min}$. The tube was then cooled in ice water and the absorbance measured spectrophotometrically at $480 \mathrm{~nm}$. Calibration curve with D-fructose (0-200 $\mu \mathrm{g} / \mathrm{ml}$ ) was prepared. One unit of activity was defined as the amount of enzyme that released $1 \mu \mathrm{g}$ fructose per min under the assay condition.

\section{Purification of Glucose Isomerase}

The obtained crude extract of glucose isomerase was precipitated with $40 \%-80$ $\%)$ ammonium sulphate. It was kept at $4{ }^{\circ} \mathrm{C}$ overnight then centrifuged at $6000 \mathrm{~g}$ for 20 min. The pellet was collected and then dissolved in $100 \mathrm{mM}$ phosphate buffer $(\mathrm{pH}$ 7.5). Ammonium sulphate precipitated samples were tested for enzyme activity and protein then were further subjected to gel filtration-using Sephadex G-200.

\section{Protein Content}

Protein content was determined by the method of Bradford (1976) using bovine serum albumin as a standard.

\section{Influence of Temperature and $\mathrm{pH}$ on Enzyme}

Activities of glucose isomerase activity was determined under standard assay conditions at different temperatures $20-70{ }^{\circ} \mathrm{C}$. The optimal $\mathrm{pH}$ value was determined at $\mathrm{pH}$ values ranging from 2.0 to 9.0 .

\section{The Effect of Metal Ions}

The effect of metal ions $\mathrm{Zn}^{+2}, \mathrm{Cd}^{+2}, \mathrm{Mn}^{+2}$, $\mathrm{Co}^{+2}, \mathrm{Ca}^{+2}$ and $\mathrm{Na}^{+}$on the enzyme activity at $5 \mathrm{mM}$ was studied. They were assessed by including each cation individually in the reaction mixture of the enzyme $50^{\circ} \mathrm{C}$ for 30 min and then assaying the residual enzymatic activity under standard conditions.

\section{The Effect of Anions}

Various anions namely arsenate, azide, bromide, fluoride and sulfate were tested as sodium salts. They were tested at $10 \mathrm{mM}$ in the reaction mixture.

\section{Effect of Amino and 2-oxo Acids}

The effect of some amino acids including glycine, tyrosine, phenylalanine, arginine, asparagine and cysteine was investigated at $10 \mathrm{mM}$ in the reaction medium. The 2 -oxo acids pyruvate, 2-oxo-glutarate and glyoxalate were tested in the reaction medium at various concentrations $(5,10,15$, 20, 25 and $30 \mathrm{mM})$.

\section{Results and Discussion}

\section{Purification of Glucose Isomerase}

Glucose isomerase was purified with ammonium sulphate and Sephadex G-150. The specific activity, yield and the fold of purification were calculated. The results are shown in Table 1 . These results indicate that the obtained specific activity was 42.8 units $\mathrm{mg}^{-1}$ protein. The yield was $64.6 \%$ with 15.8-fold of purification. Similar results were reported for the enzyme from Arthrobacter nicotiane (Sapunova et al., 
2010) where the enzyme was purified with 16-fold. Also the enzyme was purified with 42.8 units mg protein from Streptomyces SP. CH7 (Chanitnun and Pinphanichakarn, 2012). Glucose isomerases produced by Thermoanaerobacter strain B6A and Clostridium thermosulfurogenes strain 4B were purified 10-11-fold (Lee and Zeikus, 1991).

\section{Effect of Temperature on Glucose Isomerase}

This experiment was carried out to find out the optimal temperature for glucose isomerase. Therefore, the enzyme activity was measured at various temperatures 20, 30, 40, 50, 60 and $70^{\circ} \mathrm{C}$. The results in Fig. 1 show that the enzyme activity increased continuously by increasing the temperature until it reached $50^{\circ} \mathrm{C}$, after which there was a continuous decline and reached 16.8 units $\mathrm{mg}^{-1}$ protein at $70^{\circ} \mathrm{C}$. This result is in harmony with the finding of Nwokoro (2015) for the enzyme Bacillus licheniformis. The enzyme from Streptomyces sp. had maximal activity at $85^{\circ} \mathrm{C}$ (Chanitnun and Pinphanichakarn, 2012).

\section{Effect of $\mathbf{p H}$ on Glucose Isomerase Activity}

The enzyme activity was measured at various $\mathrm{pH}$ values $(2,3,4,5,6,7,8$ and 9). The results in Fig. 2 show that there was a continuous increase in the enzyme activity with increasing the $\mathrm{pH}$ up to $\mathrm{pH} 7.0$ where the enzyme activity was 33.4 units $\mathrm{mg}^{-1}$ protein after which the activity reduced continuously at $\mathrm{pH} \quad 8.0$ and $\mathrm{pH} \quad 9.0$. Therefore, it is apparent that the $\mathrm{pH}$ optimum for glucose isomerase in the present study was 7.0 which is in agreement with that reported for the enzyme from Streptomyces sp. $\mathrm{CH} 7$ (Chanitnun and Pinphanichakarn, 2012). However, lower optimum $\mathrm{pH}$ (6.0) for glucose isomerase from Bacillus licheniformis was reported by Nwokoro (2015).

\section{Effect of Glucose on Glucose Isomerase Activity}

This experiment aimed to investigate the effect of various glucose concentrations (2, $4,6,8$ and $10 \mathrm{mM}$ ) on the activity of glucose isomerase. The results in Fig. 3 show that there was continuous increase in glucose isomerase activity with increasing the substrate concentrations up to $8 \mathrm{mM}$ where the activity was 21.4 units $\mathrm{mg}^{-}$ ${ }^{1}$ protein. However, at $10 \mathrm{mM}$ little decline in the activity of the enzyme was observed where the activity was 21.2 units $\mathrm{mg}^{-}$ ${ }^{1}$ protein.

\section{Effect of Some Vitamins on Glucose Isomerase Activity}

This experiment aimed to study the effect of two vitamins ascorbic acid and folic acid on the enzyme activity. Each vitamin was tested at both 1 and $2 \mathrm{mM}$. The results in Fig. 4 show that both vitamins activated the enzyme with different rates. Folic acid was better activator than ascorbic acid at the two tested concentrations. The enzyme was activated by $14 \%$ and $38 \%$ in presence of 1 $\mathrm{mM}$ and $2 \mathrm{mM}$ folic acid, respectively. It was reported that these two vitamins increased paraoxonase, arylesterase, creatine kinase, lactic dehydrogenase, and alkaline phosphatase activities (Gursu et al., 2004).

\section{Effect of some Cations on Glucose Isomerase Activity}

This experiment aimed to investigate the effect of cations including $\mathrm{Zn}^{2+}, \mathrm{Cd}^{2+}, \mathrm{Mn}^{2+}$, $\mathrm{Co}^{2+}, \mathrm{Ca}^{2+}$ and $\mathrm{Na}^{+}$on the enzyme activity. The examined cations were in the form of sulfate salt. Each was tested at $5 \mathrm{mM}$. The results in Fig. 5 indicate that the cations 
$\mathrm{Zn}^{2+}, \mathrm{Cd}^{2+}$ and $\mathrm{Co}^{2+}$ inhibited the activity. $\mathrm{Na}^{+}$did not show any effect, however $\mathrm{Mn}^{2+}$ and $\mathrm{Ca}^{2+}$. There have been some reports that glucose isomerases require divalent metal ions such as $\mathrm{Mg}^{2+}$ and $\mathrm{Mn}^{2+}$ as cofactors
(Lehmacher and Bisswangher, 1990; Lama et al., 2001). Nwokoro (2015) reported that the best enzyme activity from Bacillus lichniformis was observed in the presence of $\mathrm{Mg}^{2+}$.

Table.1 Summary of Purification of Glucose Isomerase

\begin{tabular}{|c|c|c|c|c|c|}
\hline $\begin{array}{c}\text { Purification } \\
\text { (fold) }\end{array}$ & $\begin{array}{c}\text { Yield } \\
(\%)\end{array}$ & $\begin{array}{c}\text { Specific } \\
\text { activity } \\
(\mathrm{U} / \mathrm{mg} \\
\text { protein) }\end{array}$ & $\begin{array}{c}\text { Total } \\
\text { activity } \\
(\mathrm{U})\end{array}$ & $\begin{array}{c}\text { Total } \\
\text { protein } \\
(\mathrm{mg})\end{array}$ & Purification step \\
\hline 1 & 100 & 2.71 & 129.9 & 47.9 & Crude extract \\
\hline 9.7 & 77.1 & 26.4 & 100.2 & 3.8 & $\begin{array}{c}\text { Ammonium sulphate } \\
40 \%-80 \%))\end{array}$ \\
\hline 15.8 & 64.5 & 42.8 & 83.9 & 1.96 & Sephadex G-150 \\
\hline
\end{tabular}

Fig.1 Effect of Temperature on Glucose Isomerase Activity

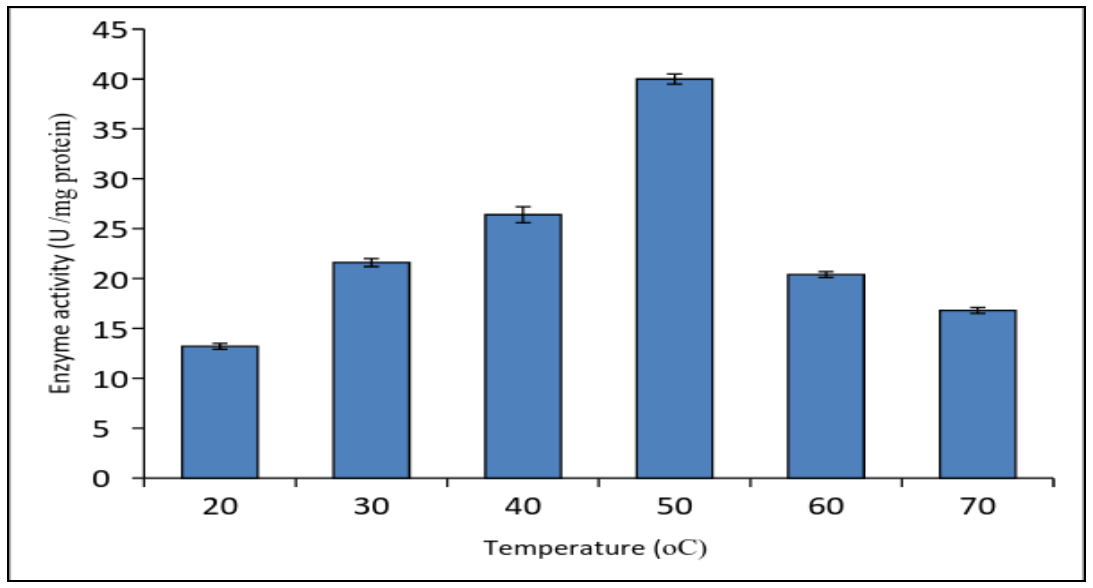

Fig.2 Effect of $\mathrm{pH}$ on Glucose Isomerase Activity

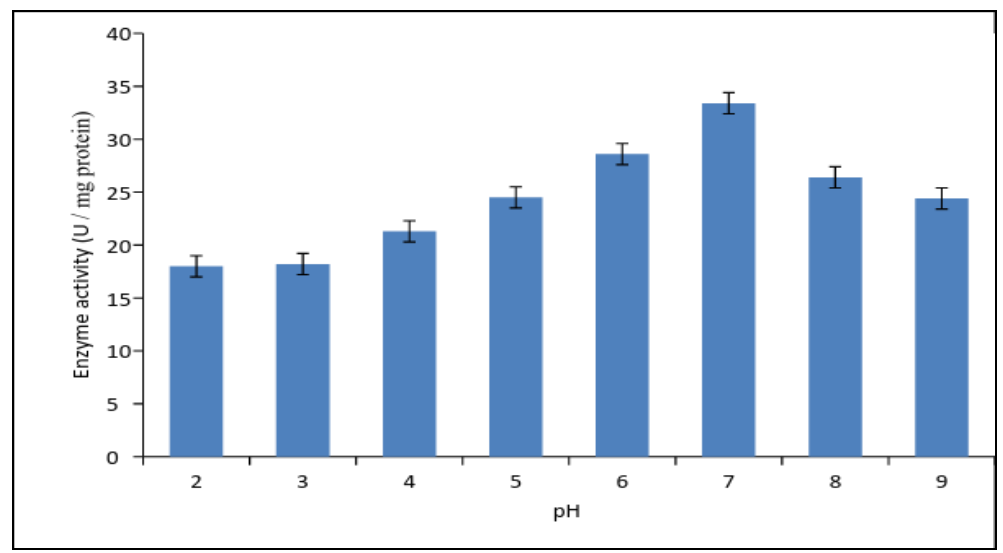


Fig.3 Effect of Various Concentrations of Glucose Isomerase on the Enzyme Activity

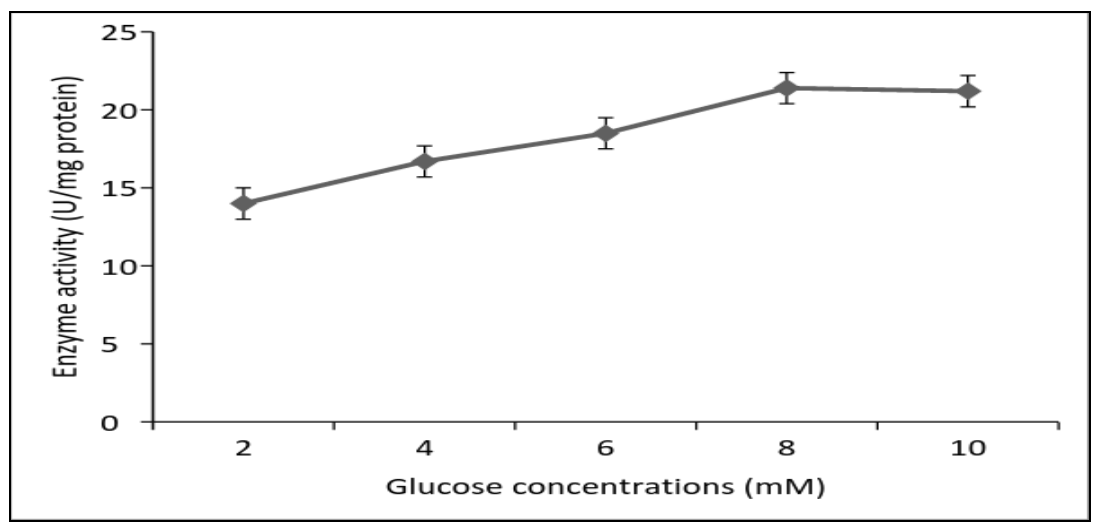

Fig.4 Effect of some Vitamins on the Rnzyme Activity

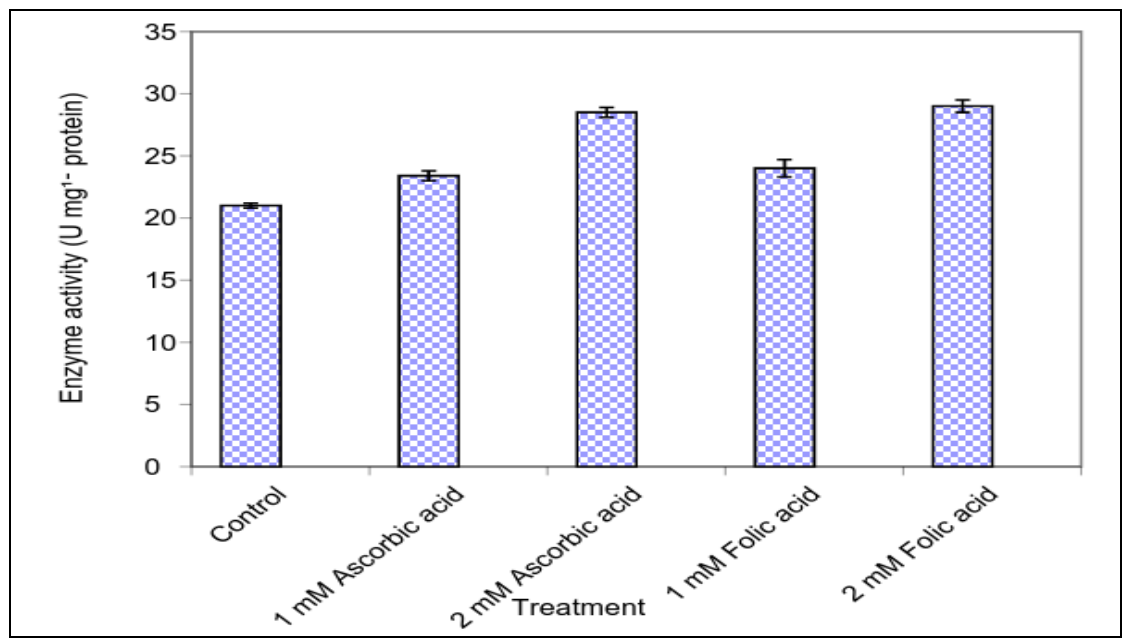

Fig.5 Effect of Various Cations on Enzyme Activity

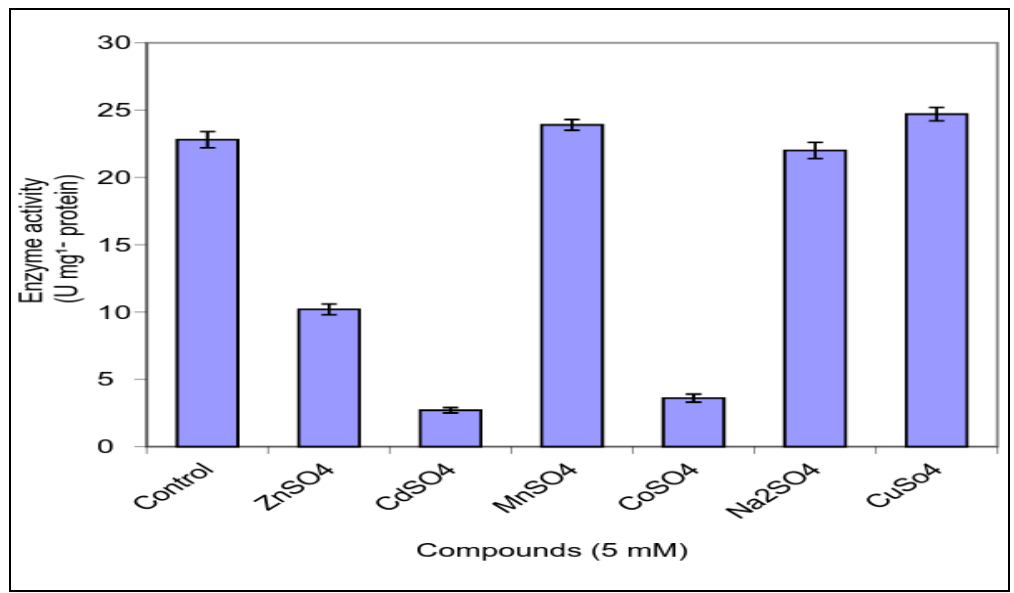


Fig.6 Effect of $\mathrm{Ca}+2$ ion on Glucose Isomerase Enzyme Activity

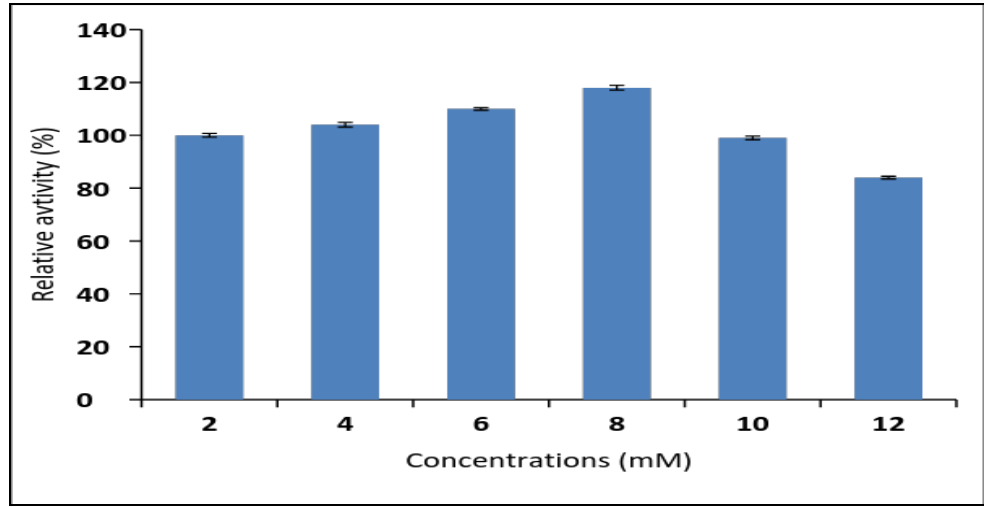

Fig.7 Effect of Anions on Enzyme Activity

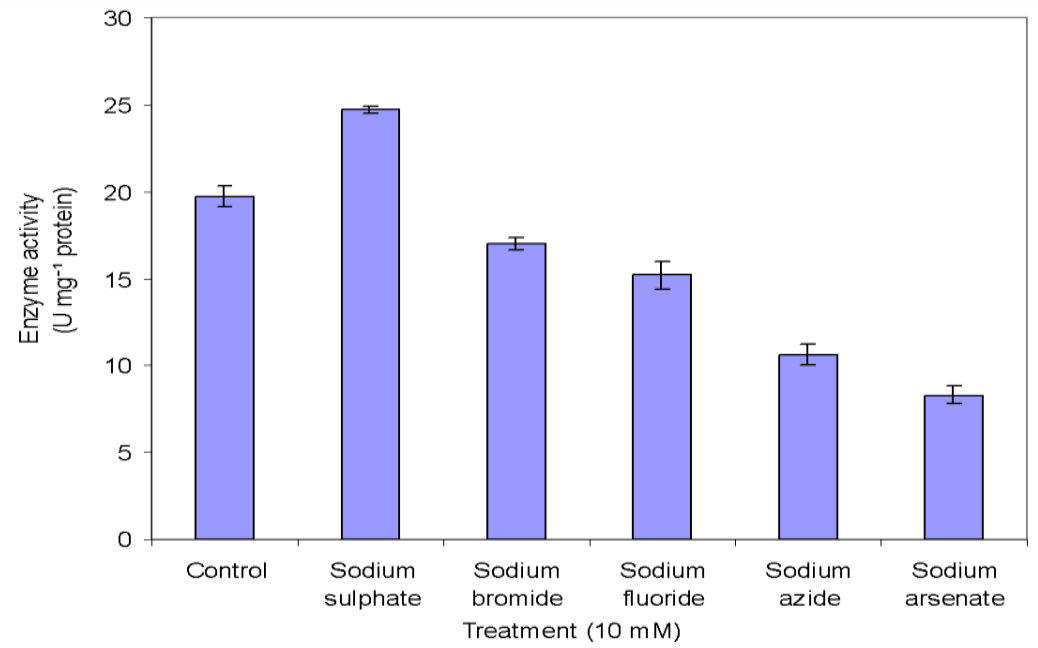

Fig.8 Effect of Amino Acids on Enzyme Activity

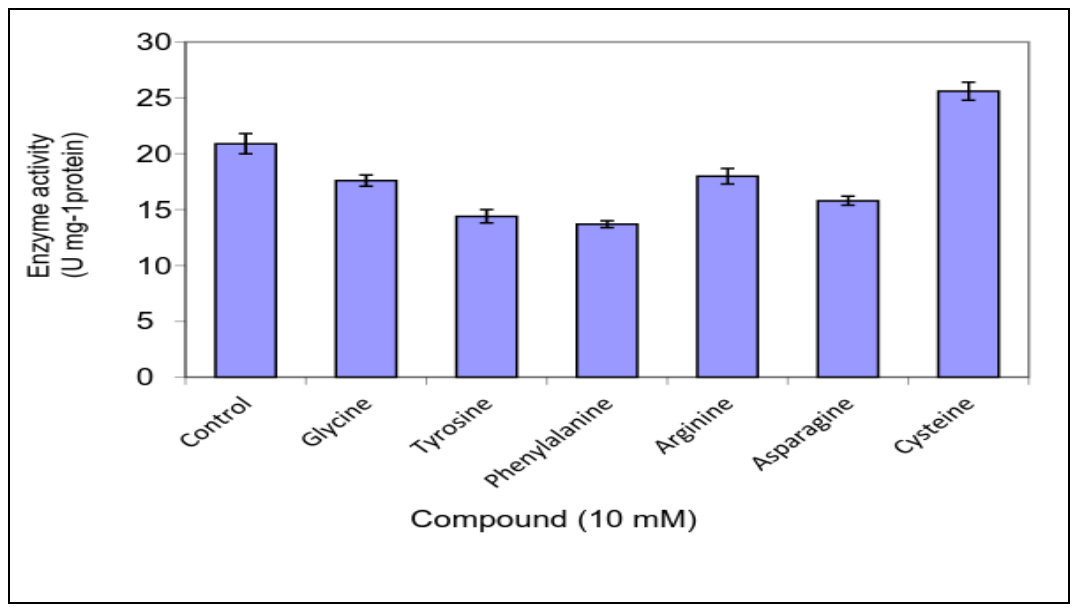


Fig.9 Effect of Guanidine $\mathrm{HCl}$ on Enzyme Activity

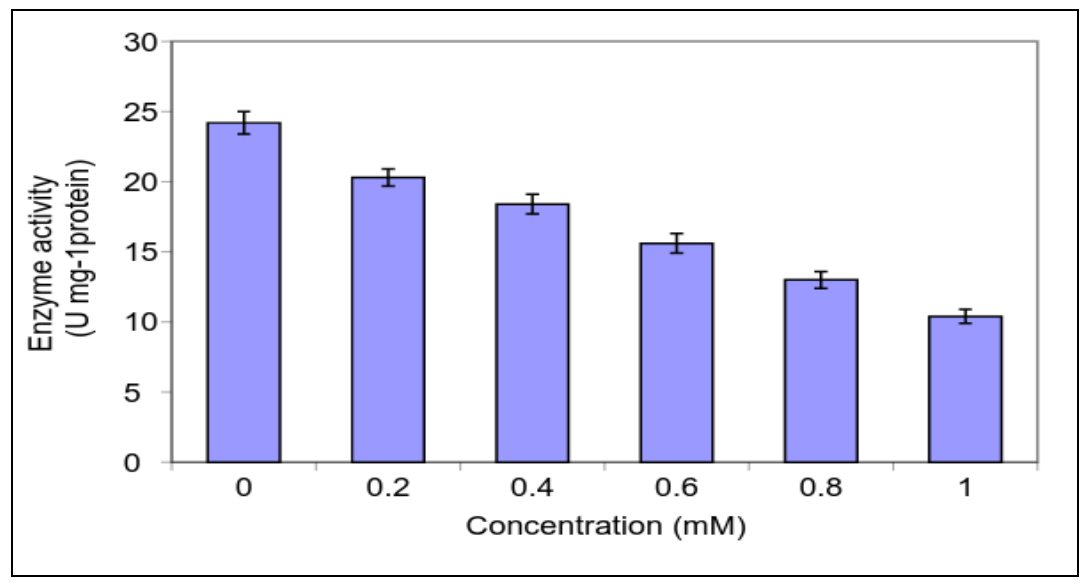

Fig.10 Effect of 2-oxo acids on Enzyme Activity

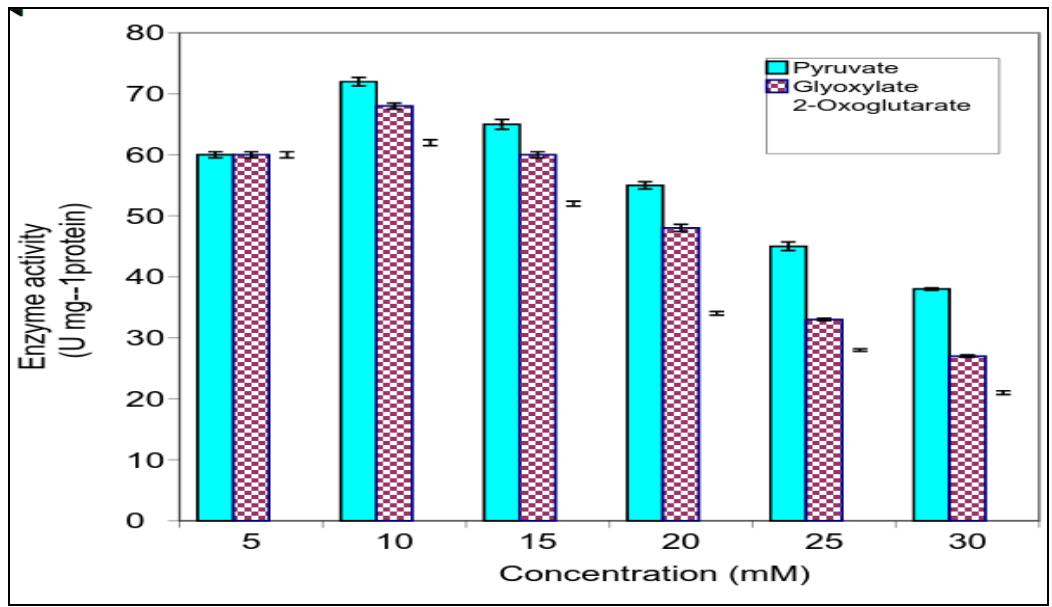

Effect of $\mathrm{Ca}^{2+}$ ions on Glucose Isomerase Activity

This experiment aimed to study the effect of various concentrations of $\mathrm{Ca}^{2+}$ on glucose isomerase activity. $\mathrm{Ca}^{2+}$ was tested at various concentrations of $\mathrm{CaCl}_{2}(2,4,6,8$, 10 and $12 \mathrm{mM}$ ). The results of these experiments are shown in Fig. 6. These results indicate that there was continuous increase in the relative activity at the concentrations 2, 4, 6 and $8 \mathrm{mM} \mathrm{CaCl}_{2}$ where the relative activities were $100 \%$, $104 \%, 110 \%$ and $118 \%$, respectively. The reason for the increase in the enzyme activity by $\mathrm{Ca}^{2+}$ may be due to the stabilization of the enzyme in its active conformation rather than or it is involved in the catalytic reaction (Strongin, 1978; ElShora and Abo-Kassem, 2001).

\section{Effect of some Anions on Glucose Isomerase Activity}

The effect of various anions on glucose isomerase was investigated. The anions were arsenate, azide, bromide, fluoride and sulfate. All anions are used as sodium salts. They were tested at $10 \mathrm{mM}$ in the reaction mixture. The results in Fig. 7 show that all 
the tested anions inhibited the enzyme activity with different rates except sulfate was activator. The activity in presence of sodium sulphate was $24.7 \mathrm{Umg}^{-1}$ protein which was higher than that of the control value (19.7 $\mathrm{Umg}^{-1}$ protein). Arsenate inhibited other enzymes (El-Shora and Lila, 2011; EL-Shora and Abd El-Gawad, 2014) Arsenate inhibition for enzymes is believed to be due to its ability to bind protein thiols (Hu et al., 1998). Bromide and fluoride inhibited other enzymes (El-Shora and Metwally, 2009).

\section{Effect of Amino Acids on Glucose Isomerase Activity}

The effect of various amino acids on the enzyme activity was studied. These amino acids were glycine, tyrosine, phenylalanine, arginine, asparagine and cysteine. Each amino acid was tested at $10 \mathrm{mM}$ in the reaction mixture. The results in Fig. 8 indicate that all tested amino acids inhibited the enzyme activity with various rates with exception of cysteine which activated the enzyme. The activity in presence of cysteine was 25.6 units $\mathrm{mg}^{-1}$ protein which was higher than that recorded for the control (20.9 units $\mathrm{mg}^{-1}$ protein). Cysteine activated other enzymes such as tyrosinase (El-Shora and Hegazy, 2014). These results reveal that SHgroup of glucose isomerase may be protected during the incubation time or cysteine activated the enzyme through lowering its $\mathrm{K}_{\mathrm{m}}$ for the substrate.

\section{Guanidine-HCl (Gdn-HCl) on Glucose Isomerase Activity}

Effect of $\mathrm{Gdn}-\mathrm{HCl}$ on the enzyme activity was investigated using different concentrations $0.2,0.4,0.6,0.8$ and $1.0 \mathrm{mM}$ in the reaction mixture. The results in Fig. 9 show that increasing the $\mathrm{Gdn}-\mathrm{HCl}$ concentration resulted in inhibition of the glucose isomerase activity. The reduction in the activity reached 10.4 units $\mathrm{mg}^{-1}$ protein at $1.0 \mathrm{mM}$ compared to that of the control values (24.2 units $\mathrm{mg}^{-1}$ protein). $\mathrm{Gdn}-\mathrm{HCl}$ could be ionized to $\mathrm{Gdn}$ and $\mathrm{Cl}$ ions in aqueous solution as being a salt and then possibly masked the positively and negatively charged amino acids of the enzyme. Therefore, $\mathrm{Gdn}-\mathrm{HCl}$ contained a strong ionic strength at high concentration and hence disrupted the enzyme and destabilized electrostatic interactions or reduced stability (Muzammil, 2000).

\section{Effect of 2-oxo acids on Glucose Isomerase Activity}

This experiment was carried out to investigate the effect of various keto acids namely pyruvate, glyoxylate and 2-oxoglutarate in the reaction medium glucose isomerase. These compounds were tested at various concentrations 5, 10, 15, 20, 25 and $30 \mathrm{mM}$. The results in Fig. 10 indicate that the three compounds activated the enzyme at the lower concentration ( 5 and $10 \mathrm{mM}$ ) but the activity was inhibited by the higher concentrations.

In conclusion, glucose isomerase was purified with appreciable activity from Bacillus thuringiensis which can be used as a source for the enzyme.

\section{References}

Antrim, R. L., Colilla, W. and Schnyder, B. J. (1979). Glucose isomerase production of high fructose syrups. Appl. Biochem. Bioeng. 2: 97-155.

Bangrak, P.; Limtong, S. and Phisalaphong, M. (2011). Continuous ethanol production using immobilized yeast cells entrapped in loofa-reinforced 
alginate carriers. Braz. J. Microbiol. 42: 676-684.

Barker, S. A., Somers, P. J. and Hatt, B. W. (1973). (Boehringer Mannheim $\mathrm{GmbH})$. Fructose. U.S. patent 3:140.

Belfaquih, N. and Penninckx, M.J. (2000). A bifunctional, xylosidase xylose isomerase from Streptomyces sp. EC10. Enzyme Microl. Technol. 27: 114-121.

Bradford, M. (1976). A rapid and sensitive method for the quantitation of microgram quantities of protein utilizing the principle of protein-dye binding. Anal. Biochem. 72: 248254.

Chen, W. (1980). Glucose isomerase. Process Biochem Process Biochem. 15: 36-41.

Deshmukh, S.S.; Deshpande, M.V. and Shankar, V. (1994). Medium optimization for the production of glucose isomerase from thermophilic Streptomyces thermonitrificans. World. J. Microbiol. Biotechnol. 10: 264-267.

El-Shora, H.M. and Abd El-Gawad, A.M. (2014). Environmental toxicity of arsenic on lupine (Lupinus termis L.) as C3 crop plant and possible alleviation. Inter. J. Agric. Crop Sci. 7(10): 687-692.

El-Shora, H.M. and Abo-Kassem, E.M. (2001). Kinetic characterization of glutamate dehydrogenase of marrow cotyledons. Plant Science, 161:10471057.

El-Shora, H.M. and Hegazy, M. (2014). Effect of amino acids and aldehydes on tyrosinase activity from marrow. J. Plant Production, Mansoura University, Egypt, 5: 295-303.

El-Shora, H.M., and Lila, A.E. (2011). Phytotoxicity of arsenate on pigment content and photosynthetic enzymes of marrow plants. Proceedings of the Third International Congress on Arsenic in the Environment (AS2010). Pp 90.

Hamed M. El-Shora and M. Metwally, (2009). Effect of phytohormones and group selective reagents on acid phosphatase from Cladosporium cladosporioides. Asian Journal of Biotechnology, 1: 1-11.

Givry, S. and Duchiron, F. (2007). Optimization of culture medium and growth conditions for production of L-arabinose isomerase and D-xylose isomerase by Lactobacillus bifermentans. Microbiology. 77: 281-287.

Gursu, M., Onderci, M., Gulcu, F. and Sahin, K. (2004). Effects of vitamin $\mathrm{C}$ and folic acid supplementation on serum paraoxonase activity and metabolites induced by heat stress in vivo. Nutr. Res. 24: 157-164.

Hemmingsen, S. H. (1979). Development of an immobilized glucose isomerase Lama, L.; Nicolaus, B.; Calandrelli, V.; Romano, I.; Basile, R. and Gambacorta, A. (2001). Purification and characterization of thermostable xylose(glucose) isomerase from Bacillus thermoantarcticus. J. Ind. Microbiol. Biotecnol., 27:234-240.

$\mathrm{Hu}$, Y., Su, L. and Snow, E.T. (1989). Arsenic toxicity is enzyme specific and its effects on ligation are not caused by the direct inhibition of DNA repair enzymes. Mutat. Res. 11: 203-218.

Kulka, R.G. (1956). Colorimetric estimation of ketopentoses and ketohexoses. Biochem J. 63: 542-548. PMID 13355847.

Lee, C. and Zeikus, J. G. (1991). Purification and characterization of thermostable glucose isomerase from Clostridium thermosulfurogenes and 
Thermoanaerobacter strain B6A. Biochem. J., 273: 565-571.

Lehmacher, A. and Bisswangher, H. (1990). Isolation and characterization of an extremely thermostable D-xylose isomerase from Thermus aquaticus HB8. J. Gen. Microbiol. 136: 679686.

Mohammadi, A.; Razavi, S.H.; Mousavi, S.M. and Rezaei, K. (2011). A comparative between sugar consumption and ethanol production in wort by immobilized Saccharomyces cerevisiae, Saccharomyces ludwigii and Saccharomyces rouxii on brewer's spent grain. Braz. J. Microbiol. 42: 605-615.

Muzammil, S., Kumar, Y. and Tayyab, S. (2000). Anion-induced stabilization of human albumin prevents the formation of intermediate during denaturation. Prot. Struct. Funct. Genet., 40: 29-38.

Nwokoro, O. (2015). Studies on the production of glucose isomerase by Bacillus lichniformis. Polish J Chem. Technol. 17: 84-88.
Sapunova, L.I.; Tamkovich, I.O. and Lobanok, A.G. (2010). Some aspects of xylose isomerase constitutive biosynthesis in Arthrobacter nicotianae. Appl. Biochem. Microbiol. 46: 438-442.

Strongin, A. Y., Izotova, L. S., Abramov, Z. T., Gorodetsky, D. I., Ermakova, L. M., Baratova, L. A., Belyanova, L. P. and Strepanov, V. M. (1978). Intracellular serine protease of Bacillus subtilis: sequence homology with extracellular subtilisins. $J$. Bacteriol. 133: 1401-1411.

Tao, N.G.; Gao, Y.M, and Liu, Y.J. (2011). Isolation and characterization of a Pichia anomala strain: a promising candidate for bioethanol production. Braz. J. Microbiol. 42): 668-675.

Verhoff, F. H., Boguslawski, G., Lantero, O. J., Schlager, S. T. and Jao, Y. C. (1985). Glucose isomerase, In: M. Moo-Young (ed.), Comprehensive Biotechnology, Vol. 3. Pergamon Press, New York. pp. 837-859.

\section{How to cite this article:}

Hamed M El-Shora, Ahmed M El-Shobaky and Jehan E Ghoneim. 2016. Activity of Glucose Isomerase from Bacillus thuringiensis under Different Treatments. Int.J.Curr.Microbiol.App.Sci.5(2): 579-589. doi: http://dx.doi.org/10.20546/ijcmas.2016.502.065 